\title{
Treatment of Recalcitrant Viral Warts with Photodynamic Therapy with Mal and Red Light
}

\author{
Montserrat Fernández Guarino*, Antonio Harto, Pedro Jaén
}

Dermatology Departament, Hospital Universitario Ramón y Cajal, Madrid, Spain.

Email: *montsefdez@msn.com

Received January $21^{\text {st }}, 2013$; revised February $23^{\text {rd }}, 2013$; accepted March $4^{\text {th }}, 2013$

\begin{abstract}
Background: Photodynamic therapy (PDT) is a treatment for non-melanoma skin cancer. In recent years, its use has expanded to new indications. Viral warts (VW) are some of the most promising. Methods: A retrospective, descriptive, observational study was carried out. Patients who did not respond to cryotherapy were selected and were occluded with methyl aminolevulinate (MAL) for three hours and they were illuminated with red light. Tolerance to treatment was evaluated using a visual analog scale for pain (from 0 to 10). Results: A total of 15 patients with 134 VW were treated. A complete response was obtained in 13 of 15 patients (87\%) and in 127 of 134 lesions (95\%). The mean number of sessions was 3.1 (range 1 to 6 ) and the average pain score was 3.1 (range 0 to 8 ). Conclusions: PDT is a treatment that offers good results in the treatment of VW that are resistant to routine treatment. The treatment was well tolerated in our patient group.
\end{abstract}

Keywords: Photodynamic Therapy; Viral Warts; Red Light

\section{Background}

Photodynamic therapy (PDT) is a technique that is increasingly being used for off-label indications. Viral warts (VW) are one of the most promising indications. Previous studies indicate clearances of between $42 \%$ $92 \%$ of lesions with aminolevulinic acid (ALA) and different incoherent light sources $[1,2]$. The primary limitation of this treatment is pain.

\section{Objective}

The purpose of our study was to evaluate the results of PDT in the treatment of VW with methyl aminole-vulinate (MAL) and red light and to evaluate treatment tolerance.

\section{Material and Methods}

A retrospective, descriptive, observational study was carried out. Patients who did not respond to at least one correctly-applied routine treatment, always including cryotherapy, were selected. After curettage of the lesions, MAL was occluded for 3 hours and illuminated with red light (Aktilite ${ }^{\circledR}, 630 \mathrm{~nm}, 37 \mathrm{~J} / \mathrm{cm}^{2}, 8$ minutes). Three sessions were applied, once per week for three weeks. The patient rested for three-week and another three-week

\footnotetext{
"Corresponding author.
}

cycle was applied (once per week) until a response was obtained. Afterwards, patients were subjected to quarterly follow-up for one year without treatment. Pain was measured after each session using a visual analog scale of 0 to 10 .

\section{Results}

A total of 15 patients with $134 \mathrm{VW}$ were treated (Table 1) A complete response was obtained in 13 of 15 patients $(87 \%)$ and in 127 of 134 lesions (95\%), see Figures 1 and 2. The mean number of sessions was 3.1 (range 1 to 6 ) and the average pain score was 3.1 (range 0 to 8 ).

\section{Discussion}

VW is a common pathology that is treated with keratolytics, cryotherapy, electrocoagulation and antimitotic agents (podophyllin, bleomycin, retinoids). More recently, new therapeutic approximations have been used with immunomodulators such as imiquimod cream, laser or PDT. Cryotherapy continues to be the most widely used treatment due to its simplicity, safety, speed, efficacy and low cost. However, it is not uncommon to encounter persistent VWs despite multiple cryotherapy sessions.

There are several mechanisms of action that explain the antiviral properties of PDT. First, the HPV-infected 
Table 1. Results of the treatment.

\begin{tabular}{|c|c|c|c|c|c|}
\hline $\begin{array}{l}\text { NUMBER OF } \\
\text { PATIENTS }\end{array}$ & $\begin{array}{l}\text { NUMBER OF } \\
\text { LESIONS }\end{array}$ & $\begin{array}{c}\text { COMPLETE } \\
\text { RESPONSE/PATIENT }\end{array}$ & $\begin{array}{c}\text { COMPLETE } \\
\text { RESPONSE/LESION }\end{array}$ & $\begin{array}{c}\text { NUMBER OF } \\
\text { SESIONS (RANGE) }\end{array}$ & $\begin{array}{c}\text { PAIN } \\
\text { (RANGE) }\end{array}$ \\
\hline 15 & $\begin{array}{l}134 \\
-3 \text { sole } \\
-7 \text { periungual } \\
-123 \text { hands }\end{array}$ & $\begin{array}{l}13 / 15 \\
87 \%\end{array}$ & $\begin{array}{c}127 / 134 \\
95 \%\end{array}$ & $\begin{array}{c}46 / 15 \\
3.1 \\
(1-6)\end{array}$ & $\begin{array}{c}39 / 15 \\
2.6 \\
(0-8)\end{array}$ \\
\hline
\end{tabular}

Table 2. Published studies on PDT for verruca vulgaris.

\begin{tabular}{|c|c|c|c|c|c|c|c|c|}
\hline $\begin{array}{l}\text { AUTHOR/ } \\
\text { YEAR }\end{array}$ & $\begin{array}{l}\text { NO. } \\
\text { VW }\end{array}$ & PS & $\begin{array}{c}\text { OCCLUSI } \\
\text { ON } \\
\text { (hours) }\end{array}$ & $\begin{array}{l}\text { LIGHT } \\
\text { SOURCE }\end{array}$ & $\begin{array}{c}\text { LIGHT } \\
\text { DOSAGE } \\
\left(\mathrm{J} / \mathrm{cm}^{2}\right)\end{array}$ & $\begin{array}{l}\text { NO. OF } \\
\text { SESSIONS }\end{array}$ & $\begin{array}{l}\text { RESPONSE } \\
(\%)\end{array}$ & COMMENTS \\
\hline $\begin{array}{c}\text { Stender } \\
1999\end{array}$ & 250 & ALA & 5 & $\begin{array}{l}\text { White, blue or } \\
\text { red }\end{array}$ & 40 & 3 & $73-42-28 \%$ & -White light is more effective \\
\hline $\begin{array}{l}\text { Stender } \\
2000\end{array}$ & 232 & ALA & 4 & $\begin{array}{l}\text { Waldman } \\
590-700 \mathrm{~nm}\end{array}$ & 70 & $2-5$ & $56 \%$ & -Statistically significant compared to placebo \\
\hline $\begin{array}{l}\text { Schroeter } \\
2005\end{array}$ & 48 & ALA & $4-8$ & $\begin{array}{l}\text { Versalight } \\
400-720 \mathrm{~nm}\end{array}$ & 100 & $\begin{array}{c}1-7 \\
(\text { mean } 2.3)\end{array}$ & $88 \%$ & \\
\hline $\begin{array}{l}\text { Ziolkowski } \\
2006\end{array}$ & 18 & ALA & 4 & $\begin{array}{l}\text { Waldman } \\
400-700 \mathrm{~nm}\end{array}$ & 70 & $1-6$ & $67 \%$ & $\begin{array}{l}\text {-Previous treatment with } 3 \% \text { azone } \\
\text {-Group without azone had a } 37 \% \text { response }\end{array}$ \\
\hline $\begin{array}{l}\text { Schroeter } \\
2007\end{array}$ & 40 & ALA & 5 & $\begin{array}{l}\text { Versalight } \\
400-720 \mathrm{~nm}\end{array}$ & 100 & $\begin{array}{c}1-13 \\
(\text { mean } 4.5)\end{array}$ & $90 \%$ & -No recurrences at 6 months \\
\hline Wang 2007 & 12 & ALA & 4 & $\begin{array}{l}\text { Waldman } \\
400-700 \mathrm{~nm}\end{array}$ & 50 & $\begin{array}{c}2-4 \\
(\text { mean } 3.6)\end{array}$ & $42 \%$ & $-4 / 12$ severe pain persisted for 24 hours \\
\hline Yoo 2009 & 40 & MAL & 3 & Aktilite $630 \mathrm{~nm}$ & 50 & $\begin{array}{c}1-3 \\
(\text { mean } 2.2)\end{array}$ & $90 \%$ & -Uses first CO2 laser \\
\hline Lu 2010 & $18^{*}$ & ALA & 4 & $635 \mathrm{~nm}$ laser & 120 & Maximum 3 & $94 \%$ & -Flat warts \\
\hline $\begin{array}{c}\text { Fernandez- } \\
\text { Guarino } \\
2010\end{array}$ & 235 & MAL & 3 & PDL $395 \mathrm{~nm}$ & $\begin{array}{c}7 \mathrm{~mm} \\
9 \mathrm{~J} / \mathrm{cm} 2\end{array}$ & $\begin{array}{l}\text { Maximum of } 6 \\
(\text { mean } 5.25)\end{array}$ & $53 \%$ & $\begin{array}{l}\text {-No incomplete responses obtained } \\
\text {-Response per patient: } 26 \%\end{array}$ \\
\hline
\end{tabular}

NO.: number; VW: Viral wart; PAC: patients; PS: photosensitizer; PDL: Pulsed dye laser; ${ }^{*}$ : Number of patients with flat warts.

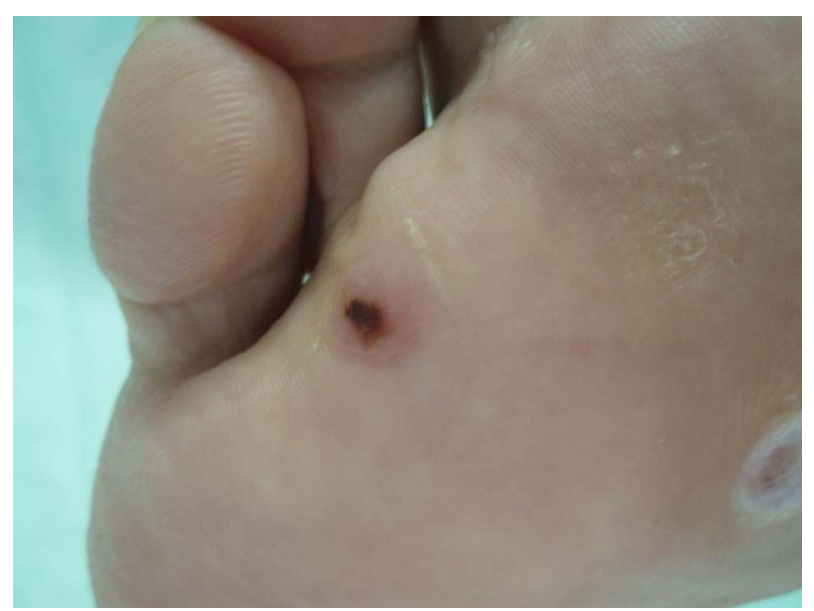

Figure 1. Image of a plantar wart previous to treatment with photodynamic therapy.

cells proliferate more rapidly than normal circulating cells. This leads to selective accumulation of the photosensitizer [3]. On the other hand, PDT has been shown to destroy infected keratinocytes and inactivate viral

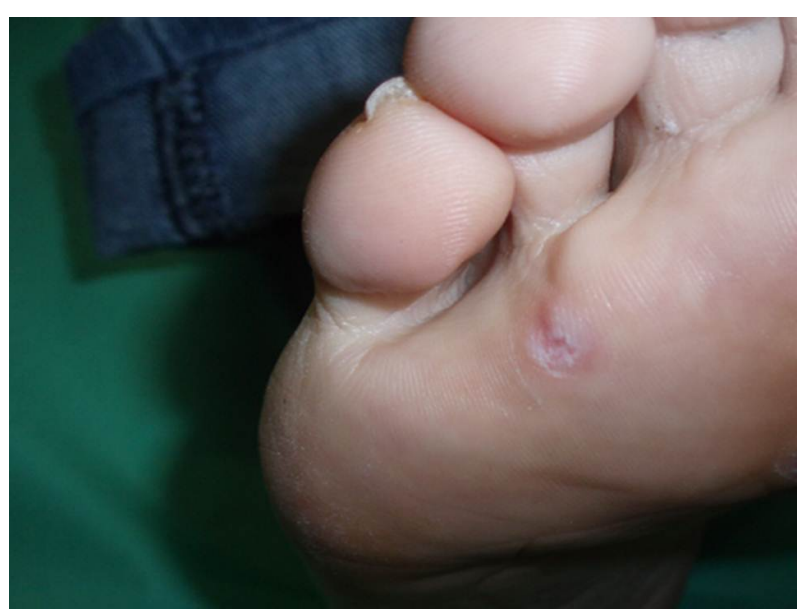

Figure 2. Image of the same plantar wart after five sessions of treatment with photodynamic therapy (MAL, red light, $630 \mathrm{~nm}, 37 \mathrm{~J} / \mathrm{cm}^{2}, 8$ minutes).

Replication [4]. Giomi, in an interesting recently published study, studied the immunological response of PDT on genital warts [5]. He found a progressive increase in 
perilesional CD4 T-lymphocytes during the first month. These findings appear to suggest that there is an ability of PDT to induce a specific immune response.

There are several published studies on the use of PDT in VW (see Table 2) [2,6-14]. These studies found an efficacy of $42 \%-90 \%$. The first studies were by Stender $[6,7]$ ALA and found that white light is more effective than red or blue. The majority of studies use ALA as the photosensitizer and long wave light sources and red surroundings in order to achieve greater penetration. One of the studies uses a diode laser with a very good response in flat warts (94\%) [13] and another uses a pulsed dye laser in verruca vulgaris with a more moderate response [14]. All used repeated sessions in order to achieve a response in the lesions and all noted that the use of ablative methods prior to PDT (keratolytics, azone, $\mathrm{CO}_{2}$ laser) increases the response to treatment by favoring penetration of the photosensitizer and the light source. $[10,11,14]$ Few studies had a long patient follow-up. Only one evaluated the response at 6 months [2]. Our results are good if we compare them to the published literature, though our study included a small patient series.

Without a doubt, the most limiting factor for treating VWs with PDT is the pain, which occurs in all treatment modalities, and leads to discontinuing the session in up to $20 \%$ of patients. [15] The pain is characteristically intense and persists for up to 24 hours after treatment. It is very notable that patients tolerated the pain well in [16] our study (mean pain of 3.1) versus previous publications. When we begin to apply PDT in the treatment of VW, we select laser as the light source in order to try and improve tolerance to treatment [14]. However, we have achieved better tolerance with red light.

PDT with MAL and red light is a promising treatment that is well tolerated in the management of VWs that are resistant to standard treatments. Nevertheless, there are few studies of adequate sample size and design that support its scientific evidence, so new studies on this subject are needed.

\section{REFERENCES}

[1] I. M. Stender, J. Lock-Anderson and H. C. Wulf, "Recalcitrant Hand and Foot Warts Successfully Treated with Photodynamic Therapy with Topical Aminolaevulinic Acid: A Pilot Study," Journal of Clinical \& Experimental Dermatology, Vol. 24, No. 3, 1999, pp. 154-159. doi:10.1046/j.1365-2230.1999.00441.x

[2] C. A. Schroeter, L. Kaas, J. J. Waterval, P. M. Bos and H. A. Neumann, "Successful Treatment of Periungual Warts Using Photodynamic Therapy: A Pilot Study," Journal of the European Academy of Dermatology and Venereology, Vol. 21, No. 9, 2007, pp. 1170-1174.

[3] E. V. Ross, R. Romero, N. Kollias, C. Crum and R. R. Anderson, "Selectivity of Protoporphyrin IX Fluorescence for Condylomata after Topical Application of 5-Aminolaevulinic Acid: Implications for Photodynamic Treatment," British Journal of Dermatology, Vol. 137, No. 5, 1997, pp. 736-742.

doi:10.1111/j.1365-2133.1997.tb01110.x

[4] J. North, H. Neyndorff, D. King and J. G. Levy, "Viral Inactivation in Blood and Red Cell Concentrations with Benzoporphyrin Derivative," Blood Cells, Vol. 18, No. 1, 1992, pp. 129-139.

doi:10.1111/j.1365-2133.2010.10089.x

[5] B. Giomi, F. Pagnini, A. Cappuccini, B. Bianchi, L. Tiradritti and G. Zuccati, "Immunological Activity of Photodynamic Therapy of Genital Warts," British Journal of Dermatology, Vol. 164, No. 2, 2011, pp. 448-451.

[6] I. M. Stender, J. Lock-Anderson and H. C. Wulf, "Recalcitrant Hand and Foot Warts Successfully Treated with Photodynamic Therapy with 5-Aminolaevulinic Acid. A Pilot Study," Journal of Clinical \& Experimental Dermatology Research, Vol. 24, No. 3, 1999, pp. 154-159. doi:10.1046/j.1365-2230.1999.00441.x

[7] I. M. Stender, R. Na, H. Fogh, C. Gluud and H. C. Wulf, "Photodynamic Therapy with 5 Aminolaevulinic Acid Placebo for Recalcitrant Foot and Hand Warts: Randomized Double Blind Trial," Lancet, Vol. 355, No. 9208, 2000, pp. 963-966.| doi:10.1016/S0140-6736(00)90013-8

[8] G. Fabbrocini, M. P. Constanzo, A. M. Riccardo, M. Quarto, A. Colasanti, G. Roberti, et al., "Photodynamic Therapy with Topical 5-Aminolaevulinic Acid for the Treatment of Plantar Warts," Journal of Photochemistry and Photobiology B, Vol. 61, No. 1, 2001, pp. 30-34. doi:10.1016/S1011-1344(01)00141-5

[9] C. A. Schroeter, J. Pleunis, V. N. Tot Pannerden, T. Reinneke and H. A. Neumann, "Photodynamic Therapy: New Treatment for Therapy Resistant Plantar Warts," Dermatologic Surgery, Vol. 31, No. 1, 2005, pp. 71-75. doi:10.1111/j.1524-4725.2005.31011

[10] P. Ziolkowski, B. J. Osiecka, M. Siewinski, A. Bronowicz, J. Ziolkowska and H. Gerber-Leszczyszyn, "Pretreatment of Plantar Warts with Azone Enhaces the Effects of 5-Aminolaevulinic Acid Photodynamic Therapy," Journal of Environmental Pathology Toxicology and Oncology, Vol. 25, No. 1-2, 2006, pp. 403-409. doi:10.1615/JEnvironPatholToxicolOncol.v25.11-2.250

[11] C. A. Schroeter, L. Kaas, J. J. Waterval, P. M. Bos and H. A. Neumann, "Successful Treatment of Periungual Warts Using Photodynamic Therapy: A Pilot Study," Journal of the European Academy of Dermatology and Venereology, Vol. 21, No. 9, 2007, pp. 1170-1174.

[12] Y. S. Wang, Y. K. Tay, C. Kwok and E. Tan, "Photodynamic Therapy with $20 \%$ Aminolevulinic Acid for the Treatment of Recalcitrant Viral Warts in an Asian Population," International Journal of Dermatology, Vol. 46, No. 11, 2007, pp. 1180-1184. doi:10.1111/j.1365-4632.2007.03210.x

[13] K. H. Yoo, B. J. Kim and M. N. Kim, "Enhanced Efficacy of Photodynamic Therapy with Methyl-5-Aminolaevulinic Acid in Recalcitrant Periungual Warts after Ablative Carbon Dioxide Fractional Laser: A Pilot Study," Dermatologic Surgery, Vol. 35, No. 12, 2009, pp. $1927-$ 
1932. doi:10.1111/j.1524-4725.2009.01307.x

[14] Y. G. Lu, J. J. Wi, Y. He, H. Z. Yang and Y. D. Yang, "Efficacy of Topical Aminolevulinic Acid Photodynamic Therapy for the Treatment of Verruca Planae," Photomedicine and Laser Surgery, Vol. 28, No. 4, 2010, pp. 561-563. doi:10.1089/pho.2009.2566

[15] M. Fernández-Guarino, A. Harto and P. Jaen, "Treatment of Recalcitrant Viral Warts with Pulsed Dye Laser MAL-
PDT," Journal of Dermatological Treatment, Vol. 22, No. 4, 2011, pp. 226-228.

[16] I. M. Stender, F. M. Borgbjerg, J. Villumsen, J. LockAndersen and H. C. Wulf, "Pain Induced by Photodynamic Therapy of Warts," Photodermatology, Photoimmunology \& Photomedicine, Vol. 22, No. 6, 2006, pp. 304309. doi:10.1111/j.1600-0781.2006.00259.x 